\title{
KIÉ A FELELŐSSÉG? KÖZVÁLLALATOK A TÁRSASÁGI JOG ÚTVESZTŐIBEN•
}

\author{
Zoványi Nikolett ${ }^{30}$
}

A közszolgáltatások ellátásának és az infrastrukturális szolgáltatások nyújtásának keretei a rendszerváltás óta változásban vannak. 1990 után a magánvállalatok erősödtek meg Magyarországon, privatizációs hullám zajlott. A 2000 évekhez közeledve azonban elkezdődött egy folyamat, Európa-szerte és Magyarországon egyaránt, melynek keretében megnőtt az igény a többségi vagy kizárólagos állami tulajdonú társasági formák iránt. Felvetődhet azonban a kérdés, hogy milyen szemléletmód-változáson kell keresztülmennie a közvállalatoknak, hogy valóban hatékonyan és átláthatóan müködjenek, és szolgálják a köz érdekét? A társasági jog különböző megoldási lehetőségeket kínál a vállalatok számára. Kérdéses azonban, hogy a magánszektor gazdasági és tulajdonosi viszonyaira kitalált modellek mennyiben képesek az állam és az önkormányzatok gazdasági igényeit is kiszolgálni egyben?

Jelen írás célja, hogy a társasági jog ezen intézményei mentén elemezze a Magasfeszültség Városi szolgáltatások című könyv ${ }^{31}$ közszolgáltatások szervezésével kapcsolatos állításait. Annál is inkább lényeges ezen jogintézmények tárgyalása, mert a Polgári Törvénykönyv ${ }^{32} 2014$ március 15 -ei hatályba lépése jelentős változásokat hozott ezen a téren.

\section{Az állam és önkormányzatok vállalkozási tevékenysége}

A gazdasági társaságok egyik leglényegesebb sajátossága és létrehozásuk alapvető célja a tagok gazdasági érdekeinek érvényesítése és kielégítése, amely profittermelés formájában nyilvánul meg. A nemzeti vagyonról rendelkező törvény ${ }^{33}$ azonban meghatároz olyan tevékenységeket és szolgáltatásokat, amelyek esetében a köz érdeke megköveteli, hogy a privátszektor valamely profitorientált szereplője kizárólag szigorú feltételek betartása mellett (koncessziós szerződés keretében) vagy adott esetben egyáltalán ne folytathassa a tevékenységet, hanem azt állami vagy önkormányzati szervek, vagy kizárólag az állam és/vagy önkormányzat tulajdonában álló gazdasági társaság folytathassa (víziközmüszolgáltatások). Az államnak és az önkormányzatoknak Alaptörvényböl (38. cikk) eredő joguk és kötelezettségük, hogy a nemzeti vagyont kezeljék és védelemben részesítsék. Ezen tevékenységeknek közvetlen célja a közérdek szolgálata, továbbá a közös szükségletek kielégítése és a természetes erőforrások megóvása.Az Alaptörvény megadja azt a felhatalmazást az államnak és az önkormányzatoknak, hogy maguk is létesíthetnek gazdasági társaságokat. A Polgári Törvénykönyv szabályainak alkalmazásán túl azonban más jogszabályok is alakítják, meghatározzák ezt a tevékenységet. A nemzeti vagyonról szóló törvény alapján (9. § (2) bekezdés) az önkormányzatok kizárólag akkor alapíthatnak

\footnotetext{
A tanulmány a Magyar Tudományos Akadémia és a Debreceni Egyetem Állam- és Jogtudományi Kar közös, MTA-DE Közszolgáltatási Kutatócsoportjának a Területi közszolgáltatások szabályozásai címü projektje keretében készült. A projekt leírására 1.: Horváth M.T.: Szempontok a területi közszolgáltatások regulációs változásainak vizsgálatához. In: HMT (szerk.) Kilengések. Közszolgáltatási változások. Budapest: Dialóg Campus, 2013. 9-25. old.

${ }^{30}$ Zoványi Nikolett, tudományos munkatárs, MTA-DE Közszolgáltatási Kutatócsoport

${ }^{31}$ HoRvÁTH M. Tamás: Magasfeszültség - városi szolgáltatások. Dialóg Campus, Budapest-Pécs, 2015.

32 2013. évi V. törvény a Polgári Törvénykönyvröl

${ }^{33} 2011$. évi CXCVI. törvény a nemzeti vagyonról
} 
gazdasági társaságot, ha e vállalkozási tevékenység nem veszélyezteti kötelező feladatainak ellátását. Behatárolt az is, hogy a Ptk.-ban szabályozott négy gazdasági társaság közül mely formák alkalmazásának lehetősége adott az állam és az önkormányzatok számára. A felelősségük mértéke ugyanis nem haladhatja meg a teljesített vagyoni hozzájárulásuk mértékét, amely követelmény csak a korlátolt felelösségü társaságra és a részvénytársaságra nézve teljesül. Az állam és/vagy önkormányzatok által alapított, valamint azon gazdasági társaságok esetén, ahol az állam- vagy az önkormányzat legalább többségi tulajdonrésszel rendelkezik, önálló és felelős gazdálkodásuk során lényeges követelmény a törvényesség, célszerüség, eredményesség és átláthatóság követelményeinek érvényesülése. A követelményeknek való megfelelés jegyében a társasági jog kínálta eszközök érkeznek segítségül, ezért is érdemes azokat vizsgálatunk tárgyává tenni.

\section{Felelős vállalatirányítás}

A közvállalatok müködése során kiemelkedik a felelős vállalatirányítás követelményének érvényesülése, annak ellenére is, hogy európai és magyar viszonylatban egy viszonylag fiatal jogintézményről van szó. A szakirodalom rámutatott arra, hogy az angol eredetücorporategovernancejogintézmény magyar elnevezése sem problémamentes, a fogalmának megfogalmazása pedig még attól is nehezebb. A fogalom értelmezésénél irányadó az OrganisationforEconomicCo-operation and Development (OECD) által kiadott ajánlás ${ }^{34}$, ami alapján alapvetően az ügyvezetés, az ellenőrzés és a részvényesek közötti különféle viszonyokat értjük a fogalom alatt.A corporategovernancetehát alapvetően a társaság vezetőinek, tulajdonosainak és egyéb érdekeltjeinek a viszonyát szabályozza, annak érdekében, hogy a vállalat irányítása átlátható és ellenőrizhető legyen. Auer Ádám ${ }^{35}$ és mások $^{36}$ rámutatnak arra, hogy ma Magyarországon éppen a közvállalatok köre, vagyis az állami vagy önkormányzati részvétellel müködő gazdasági társaságok jelentik azt a területet, ahol erőteljesen érvényesülnek a felelős vállalatirányítás követelményei (Auer Ádám: A felelős társaságirányítás megjelenése a magánjogban (viszonyítási pontok és dogmatikai következtetések), doktori disszertáció). Az Európában zajló hasonló folyamatokat felismerve az OECD ajánlást ${ }^{37}$ fogalmazott meg az állami vagy önkormányzati részvétellel müködő gazdasági társaságokra is, azok belső viszonyait tárgyalva, hiszen a közpénzek költésének átláthatónak kell lennie, biztosítva a megfelelő nyilvánosságot. A követelmények betartásáért a Magyar Nemzeti Vagyonkezelő Zrt. felelős, aki maga is megfogalmazta az OECD ajánlások alapján a magyar közvállalatokkal szembeni irányadó müködési szabályokat. ${ }^{38} \mathrm{~A}$ közpénzek elköltésének és az átláthatóság követelményének való megfelelés kikényszeríthető és ellenőrizhető kell, hogy legyen. A vezető tisztségviselőknek ezért kötelező évente felelös vállalatirányítási jelentést készíteni az adott gazdasági évről, a döntésekről, a mögöttük meghúzódó érvekről, és az intézkedések hatásairól a társaság legfőbb szerve számára. A jelentést elfogadása után nyilvánosságra is kell hozni, szintén a corporategovernance követelményeinek való megfelelés jegyében.

A felelös vállalatirányítás társadalmi szempontú ajánlásai és követelményei mellett azonban fontos szerep jut a társasági jog - a felelős vállalatirányításhoz egyébként szorosan kapcsolódó - egyéb eszközeinek, így a vezető tisztségviselők felelősségének és a vállalatirányítási formáknak.

\footnotetext{
${ }^{34}$ http://www.oecd.org/daf/ca/corporategovernanceprinciples/31557724.pdf (letöltés: 2015.november 21.)

${ }^{35}$ AUER Ádám: CorporateGovernance - Állami részvétellel müködő gazdálkodó szervezetek, Budapest: NKE, 2014.

${ }^{36}$ Többek között ld.: HoRVÁTH M. Tamás (Felelős társaságirányítás - a közszektorban? Gazdaság és Jog, $2013 / 1$. $12-16$.

${ }^{37}$ http://www.oecd.org/corporate/guidelines-corporate-governance-SOEs.htm (letöltés: 2015.november 21.)

${ }^{38} \mathrm{http}: / / \mathrm{mnvzrt.hu} /$ vallalatiranyitasi ajanlasok/vallalatiranyitasi ajanlasok.html (letöltés: 2015.november 21.)
} 


\section{Vezető tisztségviselők felelőssége}

A felelös vállalatirányítás alapvetően a társadalmi felelősséggel összefüggésben fogalmazza meg elvárásait, ugyanakkor fontos, hogy a vezető tisztségviselők elszámoltathatóak, felelősségre vonhatóak legyenek a társasággal szemben. A vezető tisztségviselők felelősségével kapcsolatban a Ptk.lényegi változásokat hozott. A vezető tisztségviselök tevékenységük során a jogi személynek okozott kárért a szerződésszegéssel okozott károkért való felelősség szabályai szerint felelnek (Ptk. 3:24.§). Ezt azt jelenti, hogy a korábban velük szemben felróhatósági alapú felelősség szemléletével szakítva objektivizálódik felelősségük. Mentesülésük érdekében azt kell bizonyítaniuk, hogy ellenőrzési körön kívüli körülmény vezetett a károsodáshoz, amely a szerződéskötés időpontjában nem volt elöre látható, és nem volt elvárható, hogy a körülményt elkerüljék vagy a kárt elhárítsák. Felelősségük ráadásul kétirányú. Egyrészt a társasággal szemben terheli őket az eljárásuk következményeiért felelősség, és harmadik személyekkel szemben is felelösséggel tartoznak.

Mindezek alapján valóban megvan a lehetőség arra, hogy a közvállalatok vezető tisztségviselöit felelősségre vonják a közpénzek költséghatékony elköltéséért. Ennek a témának a bővebb kifejtése azonban külön tanulmány tárgyát képezi.

\section{Vállalatirányítási formák}

A 2006-os gazdasági társaságokról szóló törvény ${ }^{39}$ először teremtette meg annak feltételeit, hogy a Magyarországon nyílt részvénytársasági formában müködő társaságok a klasszikus német dualista irányítási modell helyett alkalmazhatják az angolszász monista vállalatirányítási modellt. A Ptk. pedig fenntartja ezt a választási lehetőséget. Míg a német modellben elkülönült szervként müködik a vállalat operatív irányításáért és a határozatok végrehajtásáért felelős szerv, az igazgatóság és az ellenőrzési funkciókat ellátó felügyelöbizottság, addig az egységes vállalatirányítási modellben a két funkciót ellátó személyek egy szerv, az igazgatótanács keretében müködnek. Azért is különösen kedvelt forma lehet az egységes vállalatirányítási modell alkalmazása a közvállalatok körében, mert így a tényleges irányításért felelős szakértő személyek és az ellenőrzési funkciókat betöltő, az állam és az önkormányzatok érdekeit leginkább képviselő személyek egy testületben, közösen hoznak határozatokat. Ennek következtébenaz állam és/vagy önkormányzat érdekeit képviselő személyek a gazdasági társaság egész müködésére nézve megfelelő ráhatással rendelkeznek. Tulajdonosi jogaik gyakorlása során, a legfőbb szerv tagjaiként részt vesznek a döntéshozatalban, a vállalat által képviselt stratéga megalkotásában. Ezen túl a mindennapi müködésre is közvetlen hatással bírnak az ellenőrzési funkciók, végrehajtási és operatív döntések meghozatala során,hiszen ezen feladatok ellátásában részben szervezeti egységeik (ellenőrzés), részben saját munkavállalóik (közszolgák) is szerepet vállalnak. Mindez a feladatok hatékony, átlátható és gyors megoldását eredményezheti.

\section{Záró gondolatok}

A 90-es években vagy akár még a 2000-es évek elején is hitetlenkedve fogadtuk volna azt a kijelentést, hogy az állami részétellel müködő gazdasági társaságok hatékonyan tudnak müködni, a közpénzeket átláthatóan kezelni, és profitot előállítani. Mindenkiben ott élt a múlt

\footnotetext{
${ }^{39}$ 2006. évi IV. törvény a gazdasági társaságokról
} 
tudata, az állami vállalatok müködésének rengeteg negatív hozományával. Azonban az évek során Európa több államában és köztük Magyarországon is bizonyítást nyert, hogy megfelelö jogi iránymutatások és követelményrendszer mellett a közvállalatok is ugyanúgy képesek a közszolgáltatások célszerü, hatékony és gazdaságos nyújtására, mint a magánkézben lévő vállalatok.A felelős vállalatirányítás követelményei a társasági jog kínáltajogintézményekkel megtámogatva együtt valóban képesek egy megfelelően működő közvállalati rendszert kialakítására. 